(C) 1993 Elsevier Science Publishers B.V. All rights reserved 0022-0981/93/\$06.00

\title{
Day-night migrations by deep-sea decapod crustaceans in experimental samplings in the Western Mediterranean sea
}

\author{
J. E. Cartes, F. Sardà, J. B. Company and J. Lleonart \\ Institut de Ciències del Mar, Passeig Nacional s/n, Barcelona, Spain
}

(Received 24 July 1992; revision received 29 March 1993; accepted 14 April 1993)

\begin{abstract}
Analysis of abundance and size frequency data on decapod crustacean species in two different habitats (inside and outside a submarine canyon) in the Western Mediterranean during two near-continuous 24-h sampling periods using commercial bottom trawls provided an indication of migratory ability and activity of the numerically dominant species. Certain nektobenthic species (e.g. Aristeus antennatus) carried out migrations up the slope at night. Mesopelagic species, represented mainly by Pasiphaea multidentata and Pasiphaea sivado, carried out vertical migrations, more clearly distinguishable in smaller individuals. Diel behaviour tended to differ inside and outside the canyon, and possible causes are mainly discussed in the light of the morphology and feeding ecology of the species considered.
\end{abstract}

Key words: Day-night migration; Decapod crustaceans; Deep-sea; Mediterranean

\section{INTRODUCTION}

The influence of the diel cycle on species composition, density, and community structure is one of the lesser-known aspects of the study of deep-water species. Vertical migrations by the mesopelagic and demersal fauna dwelling close to the bottom have not been studied directly, though they have been discussed by certain authors (Lagardère, 1972; Gordon and Duncan, 1985). Some information is available on some species of mesopelagic crustaceans (Pasiphaeaidae, Sergestidae, Euphausiacea, Mysidacea, etc.), which are relatively dominant in bathyal benthopelagic communities (Abelló et al., 1988; Cartes, 1991) and dwell near the bottom during the daytime and migrate upwards to layers closer to the surface at night (Omori and Ohta, 1981; Lagardère, 1976; Hargreaves, 1984). Conversely, hardly any information exists on the diel cycle of activity of nektobenthic bathyal species (Maurin, 1962; Tobar and Sardà, 1987). Abundance of the species which contribute to benthic communities varies during the diel cycle, either because certain species burrow into the mud (Atkinson and Naylor, 1976; Froglia and Gramitto, 1987) or because they rise off the bottom or move up the slope (Maurin, 1962; Campillo et al., 1990).

The slope in the Western Mediterranean at depths of 400 to $1000 \mathrm{~m}$ is character-

Correspondence address: Correspondence address: J.E. Cartes, Institut de Ciències del Mar, Passeig Nacional s/n, 08039 Barcelona, Spain. 
ized by high densities of decapod crustaceans (Aristeus antennatus, Aristaeomorpha foliacea, Plesionika edwardsi, Plesionika martia, Plesionika acanthonotus, etc.). These species play important ecological and economic roles (Maurin, 1962; Tobar and Sardà, 1987, Tobar \& Sardà, 1992). Environmental light intensities in the deep-sea have been calculated as a function of light extinction in the water (Margalef, 1974) in the Catalan Sea area (Tobar \& Sardà, 1992), where a relationship between light intensity and catches in the deep-water shrimp Aristeus antennatus has been observed. Generally, daylight is still detectable to $1000 \mathrm{~m}$ (Margalef, 1974; Tyler, 1988).

The present study seeks to describe the abundance of numerically dominant decapod crustacean species recorded in samples collected during two near-continuous $24-\mathrm{h}$ sampling periods, one carried out inside a submarine canyon and the other in the external slope region neighbouring this same canyon, on the middle slope in the Catalan Sea, and to relate this to diel behaviour of such species. Size data for several species is also compared.

\section{Material AND Methods}

Two near-continuous $24-\mathrm{h}$ sampling periods were carried out on the upper middle slope (Table I) using commercial bottom trawls. The first sampling period (DN1) was carried out in the area outside the submarine canyons (Can Pere Negre) at depths between 610 and $728 \mathrm{~m}$. The second sampling period (DN2) was carried out at shallower depths (between 400 and $553 \mathrm{~m}$ ) inside a submarine canyon (Sant Salvador

TABLE 1

Sample data and location ( $\mathrm{D}=$ daytime; $\mathrm{N}=$ nighttime).

\begin{tabular}{lllllll}
\hline Station & Date & Location & Time (GMT) & D/N & $\begin{array}{c}\text { Depth } \\
\text { (m) }\end{array}$ \\
& & & Initial & Final & & \\
\hline DN1/1 & 13.07 .1989 & $41^{\prime \prime} 07^{\prime} \mathrm{N}-02^{\prime \prime} 03^{\prime} \mathrm{E}$ & 17.30 & 19.45 & $\mathrm{D}$ & $651-710$ \\
DN1/2 & 13.07 .1989 & $41^{\prime \prime} 07^{\prime} \mathrm{N}-02^{\prime \prime} 03^{\prime} \mathrm{E}$ & 21.43 & 23.51 & $\mathrm{~N}$ & $641-706$ \\
DN1/3 & 14.07 .1989 & $41^{\prime \prime} 07^{\prime} \mathrm{N}-02^{\prime \prime} 03^{\prime} \mathrm{E}$ & 01.35 & 03.46 & $\mathrm{~N}$ & $637-655$ \\
DN1/4 & 14.07 .1989 & $41^{\prime \prime} 07^{\prime} \mathrm{N}-02^{\prime \prime} 03^{\prime} \mathrm{E}$ & 05.23 & 07.26 & $\mathrm{D}$ & $675-728$ \\
DN1/5 & 14.07 .1989 & $41^{\prime \prime} 07^{\prime} \mathrm{N}-02^{\prime \prime} 03^{\prime} \mathrm{E}$ & 08.40 & 11.05 & $\mathrm{D}$ & $610-646$ \\
DN2/1 & 20.10 .1990 & $41^{\prime \prime} 07^{\prime} \mathrm{N}-01^{\prime \prime} 56^{\prime} \mathrm{E}$ & 19.45 & 21.00 & $\mathrm{~N}$ & $400-550$ \\
DN2/2 & 20.10 .1990 & $41^{\prime \prime} 07^{\prime} \mathrm{N}-01^{\prime \prime} 56^{\prime} \mathrm{E}$ & 22.08 & 11.23 & $\mathrm{~N}$ & $412-553$ \\
DN2/3 & 21.10 .1990 & $41^{\prime \prime} 07^{\prime} \mathrm{N}-01^{\prime \prime} 56^{\prime} \mathrm{E}$ & 00.15 & 01.25 & $\mathrm{~N}$ & $418-546$ \\
DN2/4 & 21.10 .1990 & $41^{\prime \prime} 07^{\prime} \mathrm{N}-01^{\prime \prime} 56^{\prime} \mathrm{E}$ & 02.25 & 03.30 & $\mathrm{~N}$ & $407-544$ \\
DN2/5 & 21.10 .1990 & $41^{\prime \prime} 07^{\prime} \mathrm{N}-01^{\prime \prime} 56^{\prime} \mathrm{E}$ & 04.25 & 05.30 & $\mathrm{~N}$ & $415-559$ \\
DN2/6 & 21.10 .1990 & $41^{\prime \prime} 07^{\prime} \mathrm{N}-01^{\prime \prime} 56^{\prime} \mathrm{E}$ & 06.16 & 07.30 & $\mathrm{D}$ & $415-546$ \\
DN2/7 & 21.10 .1990 & $41^{\prime \prime} 07^{\prime} \mathrm{N}-01^{\prime \prime} 56^{\prime} \mathrm{E}$ & 08.15 & 09.35 & $\mathrm{D}$ & $425-553$ \\
DN2/8 & 21.10 .1990 & $41^{\prime \prime} 07^{\prime} \mathrm{N}-01^{\prime \prime} 56^{\prime} \mathrm{E}$ & 10.22 & 11.37 & $\mathrm{D}$ & $410-546$ \\
DN2/9 & 21.10 .1990 & $41^{\prime \prime} 07^{\prime} \mathrm{N}-01^{\prime \prime} 56^{\prime} \mathrm{E}$ & 12.23 & 13.40 & $\mathrm{D}$ & $410-546$ \\
\hline
\end{tabular}


Canyon). Both sampling locations were situated in closely adjacent areas (less than 4 miles), and were situated on traditional fishing grounds for the red shrimp, Aristeus antennatus. Samples were obtained during the daytime and the nighttime. The DN1-1 sample (Table I) must be considered as crepuscular.

The basic features of the specific commercial bottom trawl gear employed in the red shrimp fishery are a vertical opening of $5 \mathrm{~m}$ and a horizontal opening between the wings of $25 \mathrm{~m}$. These measurements were estimated with the aid of an acoustic monitoring system (SCANRED) attached to the trawl gear. Codend mesh size was $38 \mathrm{~mm}$. Because the large mesh size used and the scarce catchability of trawls during the up and down of gear, contamination of samples by midwater species must be considered minimal.

Sampling material collected was preserved in $70 \%$ alcohol. At the laboratory the specimens in each sample were identified, counted, and weighed. Cephalothorax length (CL) was measured for the most abundant species. Only those species consistently present in the samples were considered in this study. These species comprised the penaeoidean shrimps Aristeus antennatus (Risso, 1816) and Funchalia woodwardi Johnson, 1868, the sergestid Sergia robusta (S.I. Smith, 1882); the pasiphaeids Pasiphaea multidentata Esmark, 1886 and Pasiphaea sivado (Risso, 1816), the oplophorid Acanthephyra eximia S.I. Smith, 1886, and the pandalids Plesionika acanthonotus (S.I. Smith, 1882), Plesionika martia (A. Milne Edwards, 1883) and Plesionika edwardsi (Brandt, 1851) among the natantian species. The polychelid lobster Polycheles typhlops Heller, 1862, the anomuran crab Munida tenuimana G.O. Sars, 1872, and the geryonid crab Geryon longipes A. Milne Edwards, 1881 represented the reptantian group species.

Abundance and biomass data were standardized to $1 \mathrm{~h}$, with a vessel towing speed of 2.6 knots for all hauls. Abundance and biomass of numerically-dominant species in day and night hauls were compared so as to assess the amount of diel migratory activity by species.

Size frequencies of several species were also compared in order to ascertain whether the size structure of specific population varied over the photoperiod. Size frequency distribution data were obtained for Aristeus antennatus only in three hauls (DN2-1; DN2-4; DN2-8) during DN2. In Pasiphaea multidentata (DN2) and Plesionika martia (DN1) day and night size data samples were grouped to achieve a sufficient number of individuals in the size frequencies. The percentage similarity index, used for community analyses by Goodall (1978), and Haedrich et al. (1980) among others, was calculated to determine the overlap values between size-frequency distributions within each species. This index value ranges from 0 to 1 and can be calculated according to either of the following two expressions:

$$
2 \frac{[\min (x, y)]}{(x+y)}=1 \frac{I x-y I}{(x+y)}
$$

where $x$ and $y$ are vectors representing size frequencies to be compared. Thus, the index can be regarded as the proportion of overlap in the size-distributions of the species 


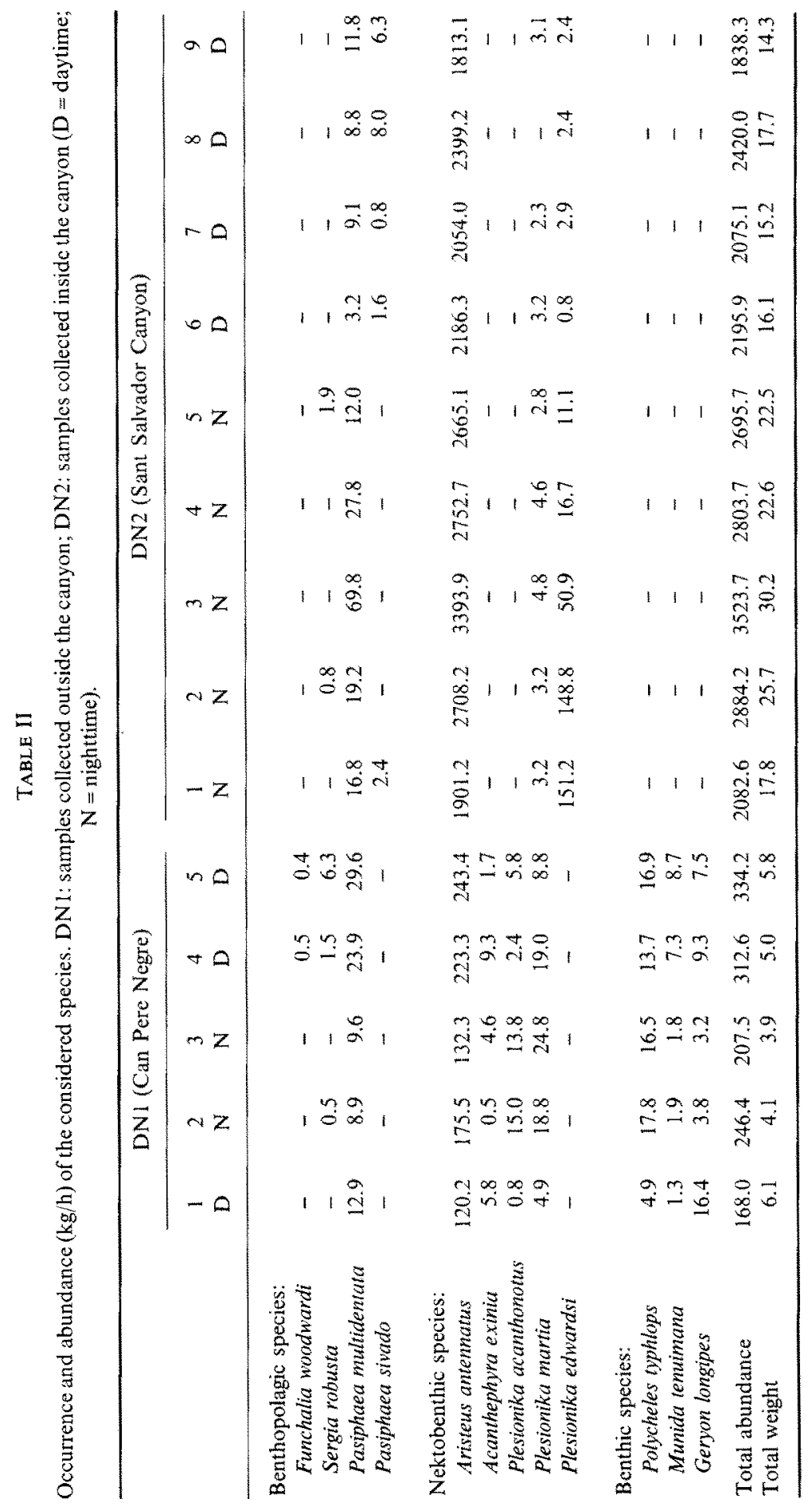


being compared, that is, the area of the intersection between size distributions divided by the sum of both the distribution areas, which since the size frequencies represent relative values, the distributions compared must expressed as a percentage.

Finally, the ratio of $\mathrm{CL}(\mathrm{mm})$ to wet weight $(\mathrm{g})$ for the species considered was plotted as an estimation of swimming ability. Two different size groups were considered in each species; small individuals, ranging in all the species between 12 and $22 \mathrm{~mm} \mathrm{CL}$, and large individuals ranging between 25 and $45 \mathrm{~mm} \mathrm{CL}$. Only in Geryon longipes range size were higher $(35-55 \mathrm{~mm} \mathrm{CL})$.

\section{RESULTS}

OUTSIDE THE SUBMARINE CANYON (DNI - CAN PERE NEGRE)

Table II sets out the abundance (ind $/ \mathrm{h}$ ) of the species in each sampling period. The mesopelagic species Pasiphaea multidentata, Sergia robusta, and Funchalia woodwardi were more abundant in daytime samples. By night catches of the latter two species were negligible as were those for Pasiphaea sivado which was found only inside the canyon (DN2).

Figure 1 represents the size frequency distribution of Pasiphaea multidentata. In the nighttime samples (DN1-2, DN1-3) most specimens were in size groups larger than 30 $\mathrm{mm}$ CL. Similarity was higher between nighttime frequencies (Table III). In the following daytime hauls (DN1-4, DN1-5) abundance shifted towards smaller modal size

TABLE III

Matrix of percentage of similarity between the size frequency distributions of the different abundant species studied during the two continous 24 -h samplings.

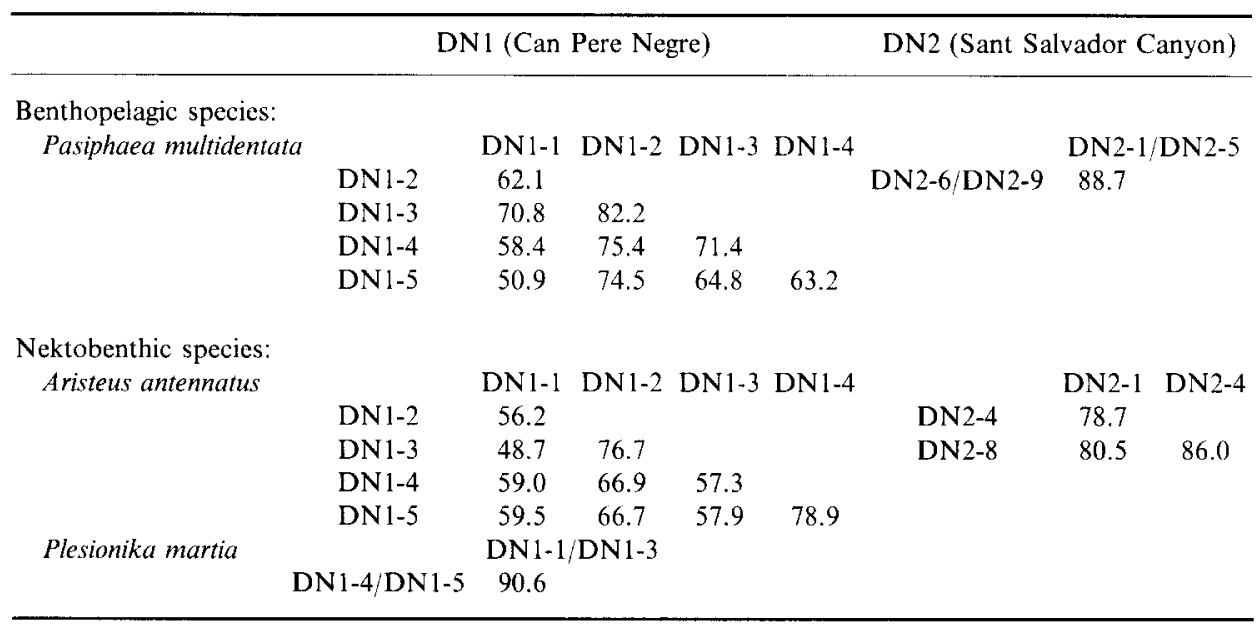


groups, with a predominance of individuals smaller than $30 \mathrm{~mm} \mathrm{CL}$ overall. This suggests that the smaller specimens, which are perhaps better able to rise through the water column (Fig. 3), migrated away from the bottom at night.

Of the nektobenthic species, the pandalids Plesionika martia and Plesionika acanthonotus were more abundant in nighttime samples (Table II). The size frequencies of Plesionika martia in the nighttime and daytime samples did not differ (Table III).

The results for Aristeus antennatus indicated that peak catches were made in the daytime. A comparison of the size frequencies (Fig. 2) yielded greater affinities between daytime samples DN1-4 and DN1-5 on the one hand and nighttime samples DN1-2 and DN1-3 on the other (Table III).

The only appreciable differences in abundance for the benthic species were recorded in the catches of Geryon longipes, which were larger in the daytime (Table II).

\section{INSIDE THE SUBMARINE CANYON (DN2 - SANT SALVADOR CANYON)}

On the whole, the pattern for the results in this area was the reverse of that outside the canyon (Table II). The highest abundance values for Pasiphaea multidentata, $\mathrm{Pa}$ siphaea sivado, Plesionika edwardsii, and Aristeus antennatus were recorded at night. Abundance levels for Plesionika martia remained relatively constant over the entire sampling period.

Nearly all Pasiphaea multidentata individuals were large (CL $>30 \mathrm{~mm})$, and there were no differences in the daytime and nighttime size frequencies (Fig. 1; Table III). In contrast to the results from DN1, Aristeus antennatus was more abundant inside the canyon at night. Smaller individuals were by far the more predominant (Fig. 2), and there was a high degree of similarity between daytime and nighttime size frequencies (Table III).

Figure 3 shows that $\mathrm{CL} /$ wet weight values were higher for mesopelagic species than for more markedly benthic species. The difference in the values for this relationship was most pronounced for adult and juvenile Pasiphaea multidentata.
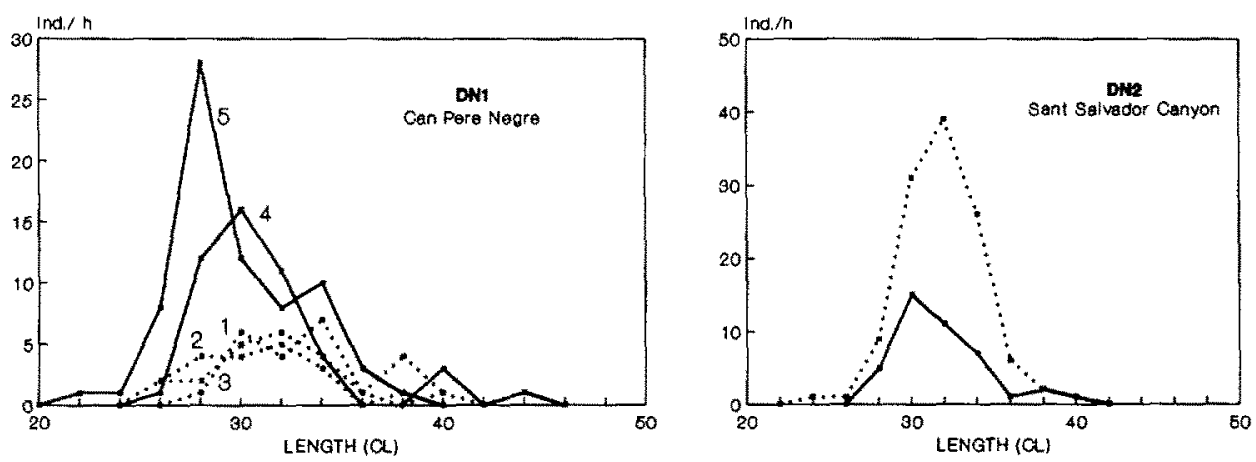

Fig. 1. Size frequency distribution (absolute values per hour) of Aristeus antennatus samples (day, continuous lines; night, discontinuous lines). Nos. $1-5=$ hauls $1-5$. 

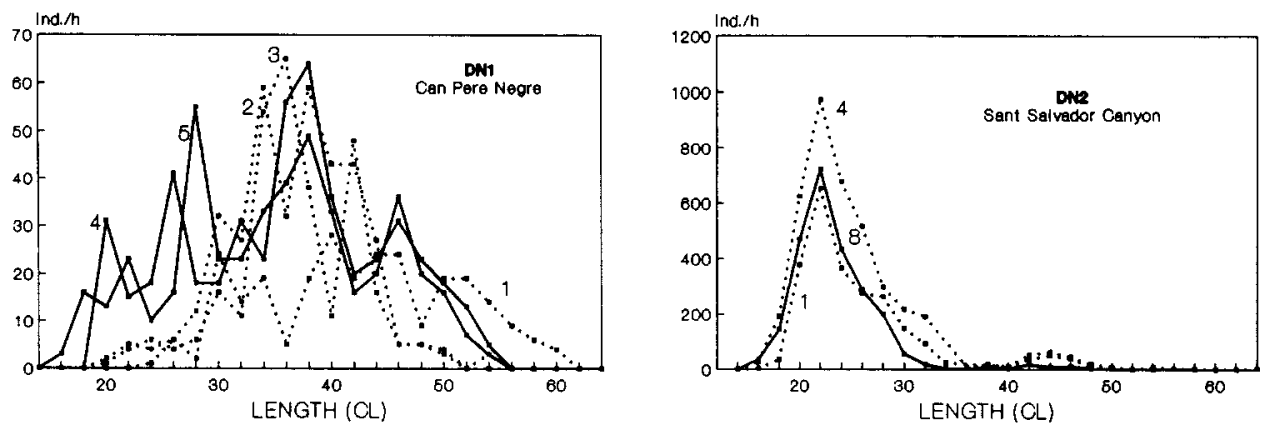

Fig. 2. Size frequency distribution (absolute values per hour) of Pasiphaea multidentata samples (day, continuous lines; night, discontinuous lines). Nos. 1-5 = hauls $1-5$.

\section{Discussion}

Mesopelagic species exhibited the most pronounced differences between daytime and nighttime samples. Pasiphaea multidentata, Funchalia woodwardi, and Sergia robusta were more abundant in the daytime samples taken outside the canyon. Large individuals of Pasiphaea multidentata ( $\mathrm{CL}>30 \mathrm{~mm}$ ) remained on the bottom at night, where they even fed on benthic resources such as gammarids, the burrowing decapod Calocaris macandreae Bell 1864, and polychaetes, while smaller individuals moved away. Conversely, during the day smaller individuals were also present on the bottom and

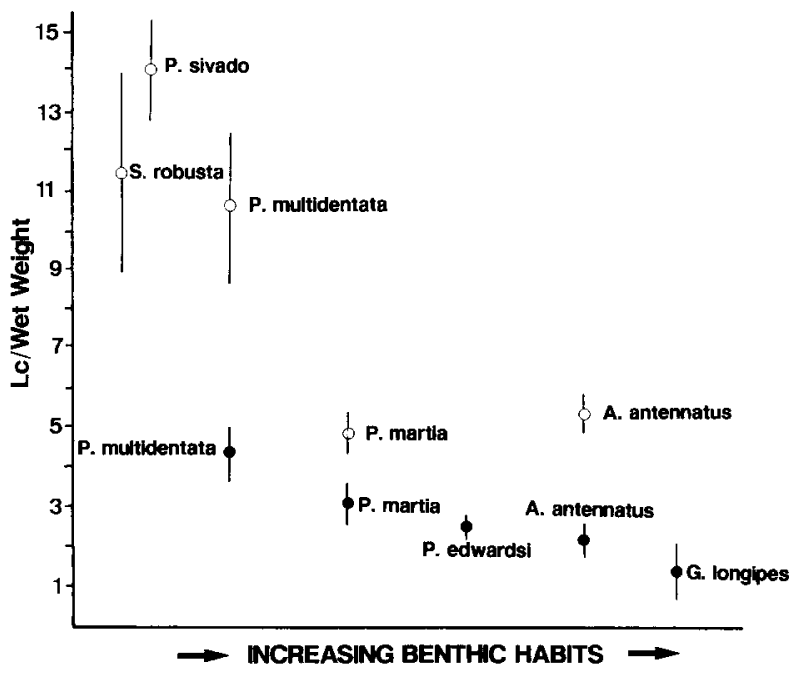

Fig. 3. Relationship between $\mathrm{CL} /$ wet weight (mean value and standard error) and benthic habits of different species considered (\&cir;, small individuals, CL between $15-20 \mathrm{~mm}$; 9 , adult individuals, CL between 25 and $35 \mathrm{~mm}$ ). 
predominated. Planktonic prey (mesopelagic fishes, euphausiids, etc.) in an advanced degree of digestion predominated in the stomach contents of these size classes (Cartes, 1991). These results were therefore indicative of vertical migration, primarily by juveniles, at night. In contrast, the behaviour of larger Pasiphaea multidentata ( $>30 \mathrm{~mm} \mathrm{CL}$ ) more closely resembled that of nektobenthic species (Figs. 3 and 4).

The differences between day and night catches of nektobenthic species were not as marked. Catches of the pandalids Plesionika edwardsi, Plesionika acanthonotus, and Plesionika martia were more variable, with an increase in catches seen at night. Lower daytime ocurrences of Plesionika martia in the net samples were consistent with its daytime diet based on mobile mesopelagic prey (Pasiphaea spp.) (Cartes, 1991) for which Plesionika martia would exhibit a higher natatory activity. Catches rose at night, when passive feeding on benthic resources took place. Even so, the high proportion of full stomachs containing food in this species were not suggestive of a vertical migration to superficial water levels during the daytime. Rather, the shoals seemed to disperse, making irregular movements towards the Benthic Boundary Layer located a few metres above the bottom (Wishner, 1980; Hargreaves, 1984, Angel, 1990), or they spread out along the bottom towards shallower or deeper areas of the slope. Aristeus antennatus also appeared to follow a similar pattern. The highest catches of this species are taken early in the daylight hours (Maurin, 1962; Tobar and Sardà, 1992), suggesting that at night the bulk of the population migrates to shallower areas of the slope or upwards to layers of the water column farther away from the bottom (Maurin, 1962; Lagardère, 1972; Campillo et al., 1990). The present findings would be consistent with migration up the slope, in this case towards submarine canyons. The high nighttime catches of $A$. antennatus found in the shallower part of the canyon might result

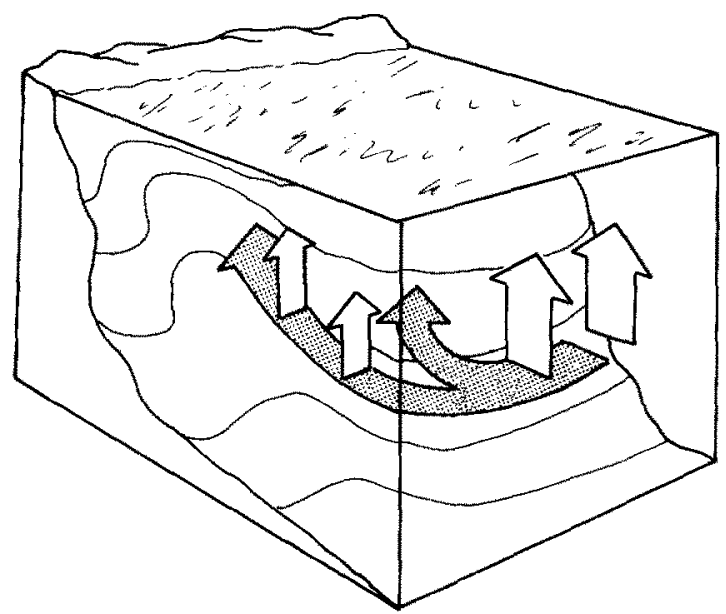

Fig. 4. Schematic representation of the hypothesis proposed for nocturnal migrations by mesopelagic species (white arrows) and nektobenthic specics (black arrows). 
from such migratory behaviour. Such is the upper depth distribution of this species in the Catalan Sea (Tobar \& Sardà, 1987; Demestre, 1990). According to available data for this area, seasonality does not appear to be responsible for the changes in abundance observed for $A$. antennatus during the two sampling periods described herein (Tobar and Sardà, 1987). Moreover, vertical migration into the water column above would seem to be an unlikely explanation, in view of the small share of planktonic prey items in the nocturnal diet of this species (Cartes, 1991).

Mesopelagic species such as Pasiphaea multidentata, Pasiphaea sivado, and Sergia robusta displayed more pronounced migratory behaviour. All these species exhibit marked morphological differences with respect to the other species: carapace and pereiopods laterally compressed and with dorsal keels present, rostrum rudimentary, all of which seem to be common adaptations to a pelagic existence exhibited by a high number of pelagic species. Thus, although certain bathypelagic oplophorid species (e.g. some Acanthephyra, and Systellapsis spp.) have relatively long rostra, the rest of morphological features after cited prevailed among them. The presence of a long rostrum in pandalids and Aristeus antennatus has been related to a more benthic behaviour related to orientational mobility and balance with respect to the sea-floor (cf. Burukovsky, 1972; Sardà and Demestre, 1989). These species may be less adapted for extensive vertical migrations, partly because of their lower $\mathrm{CL} /$ wet weight ratio (Fig. 3). In fact, these latter species were not caught in the water column (planktonic hauls). Furthermore, part of their feeding strategy appears to be based on exploitation of mesopelagic species when the latter descend close to the bottom during their own diel migrations. However, occasional penetration by these nektobenthic species into the Benthic Boundary Layer cannot be ruled out and in fact has been reported for Aristeus antennatus (Campillo et al., 1990).

In conclusion, it is suggested that there may be two different patterns responsible for diel migrations by deep-water decapod crustaceans a schematic view of which is illustrated in Fig. 4. Shoals of certain nektobenthic species seem to undergo migrations along the bottom to shallower areas of the slope at night. This might account for the relatively high biomass recorded in the canyons in the present study. The submarine canyons possibly serve as areas of aggregation at night, an aspect already confirmed for planctonic organisms (Koslow \& Ota, 1981). Particular hydrographic conditions such as up and downcanyon flows (Shepard et al., 1974; Monaco et al., 1990) or favourable food-resources (Haedrich et al., 1980; Houston \& Headrich, 1984 and references cited) occurring in the canyons perhaps could be correlated with orientation and aggregation of shoals in these areas. Thus, several species (i.e. Pasiphaea multidentata, Aristeus antennatus, and Plesionika martia) showed higher foregut fullness index in specimens taken inside rather than outside the submarine canyons in the Catalan Sea (Cartes, 1991). On the other hand, mesopelagic species apparently carried out major vertical migrations which in the present study were more discernible in small individuals. 


\section{ACKNOWLEDGEMENTS}

The authors express their appreciation to all the members of PONT'89 and PONT'90 projects, which were financied by CSIC. Thanks are due to Dr. P. Abello (ICM Barcelona) for his collaboration, and to R. Sacks for the English translation.

\section{REFERENCES}

Abello, P., F.J. Valladares \& A. Castellon, 1988. Analysis of the structure of decapod crustacean assemblages of Catalan coast (North-West Mediterranean). Mar. Biol, Vol. 98, pp. 39-49.

Angel, M.V., 1990. Life in the benthic boundary layer: connections to the mid-water and sea floor. Phil. Trant. R. Soc. Lond., Vol. 331, pp. 15-28.

Atkinson, R.J.A. \& E. Naylor, 1976. An endogenous activity rhythm and rhythmicity of catches of Nephrops norvegicus (L.). J. Exp. Mar. Biol. Ecol., Vol, 25, pp. 95-108.

Burukovsky, R.N., 1972. On the function of the rostrum in shrimps (in Russian). Trudy Atlanticheskit Nauchna-issledovatel'skii Institut Rybnogo Kozyaistva i Okeanografii (AtlantNIRO), Vol. 42, pp. 176-179.

Campillo, A., P.Y. Dremiere, B. Liorzou \& J.L. Bigot, 1990. Observations sur deux crustaces profons du golfe du Lion: Aristeus antennatus (R.) et Nephrops norvegicus (L.). FAO, Rap. sur les Pêches, Vol. 447, pp. $298-313$.

Cartes, J.E., 1991. Análisis de las comunidades y estructura trófica de los crustáceos decápodos batiales del Mar Catalán. Tesis doctoral, Universitat Politècnica de Catalunya, Barcelona, 627 pp.

Demestre, M., 1990. Biología pesquera de la gamba, Aristeus antennatus (Risso, 1816) en el mar Catalán. Tesis doctoral, Universitat de Barcelona, Barcelona, $443 \mathrm{pp}$.

Froglia, C. \& M.E. Gramitto, 1987. Notes on growth and biology of Solenocera membranacea (Risso, 1816) in the Central Adriatic Sea (Decapoda: Solenoceridae). Inv. Pesq., Vol. 51, pp. $189 \ldots 199$.

Goodall, D.W., 1978. Sample similarity and species correlation. In, Ordination of plant communties, cdited by R.H. Whittaker, Dr W. Junk by Publishers The Hague and Boston, pp. 99-151.

Gordon, J.D.M. \& J.A.R. Duncan, 1985. The ecology of the deep-sea benthic and benthopelagic fish on the slopes of the Rockall Trough, northeastern Atlantic. Prog. Oceanog., Vol.15, pp. 37-69.

Hargreaves, P.M., 1984. The distribution of Decapoda (Crustacea) in the open ocean and near-bottom over an adjacent slope in the northern North-east Atlantic ocean during Autumn 1979. J. Mar. Biol. Assuct. $U K$, Vol. 64, pp. 829-857.

Haedrich, R.L., G.T. Rowe \& P.T. Polloni, 1980. The megabenthic fauna in the deep sea south of New England, USA. Mar. Biol., Vol. 57, pp. 165-179.

Houston, K.A. \& R.L. Haedrich, 1984. Abundance and biomass of macrobenthos in the vicinity of Carson Submarine Canyon, northwest Allantic Ocean. Mar. Biol, Vol. 82, pp, 301-305.

Koslow, J.A. \& A. Ota, 1981. The ecology of vertical migrations in three common zooplankters in the La Jolla Bight, April-August 1967. Biol. Oceanogr., Vol. 1, pp. 107-134.

Lagardere, J.P., 1972. Recherches sur l'alimentation des crevettes de la Pente Continentale Marocaine. Tethys, Vol. 3, pp. 655-675.

Lagardere, J.P., 1976. Recherches sur l'alinentation des crevettes bathypelagiques du talus continentale du Golfe de Gascogne. Rev. Trav. Inst. Pêch. Marit., Vol. 39, pp. 213-229.

Margalef, R., 1974. Ecología. Ed. Omega, Barcelona, 951 pp.

Maurin, C., 1962. Eude dos fons chalutables de la Méditerranée occidentale (Ecologie et Pêche). Résultats des campagnes des navires océanographiques "Président Théodore Tissier", 1957 à 1960, et "Thalassa", 1960 et 1961. Rev. Trav. Inst. Pêch. Mar., Vol. 26, pp. 163-218.

Monaco, A., P. Biscaye, J. Soyer, R. Pocklington \& S. Heussner, 1985. The Gulf of Lions' hidrodynamics. Cont. Shelf Res., Vol. 10, pp. 809-839. 
Omori, M.\& S. Ohta, 1981. The use of underwater camera in studies of vertical distribution and swimming behaviour of a sergestid shrimp. Sergia lucens. J. Plank. Res., Vol. 3, pp. 107-120.

Sarda, F. \& M. Demestre, 1989. Shortening of the rostrum and rostral variability in Aristeus antennatus (Risso, 1816)(Deacapoda:Aristeidae). J. Crust. Biol., Vol. 9, pp. 570-577.

Shepard, F.P., N.F. Marshall \& P.A. McLoughlin, 1974. Currents in submarine canyons. Deep-sea Res., Vol. 21, pp. 691-706.

Tobar, R. \& F. Sarda, 1987. Análisis de las capturas de gamba rosada, Aristeus antennatus (Risso, 1816) en los últimos decenios en Cataluña. Inf. Téc. Inst. Cien. Mar. Barcelona, Vol. 142, pp. 1-20.

Tobar, R. \& F. Sarda, 1992. Annual and diel light cycle as a predictive factor in deeper fisheries for the prawn Aristeus antennatus (Risso, 1816). Fish. Res.

Tyler, P.A., 1988. Scasonality in the deep sea. Oceanogr. Mar. Biol. Ann. Rev., Vol. 26, pp. 227-258.

Wishner, K.F., 1980. The biomass of the deep-sea benthopelagic plankton. Deep-Sea Res., Vol. 27A, pp. 203-216. 